\title{
Presence, distribution and contamination levels of lead in the surface sediments of the Ria of Ferrol (NW Spain)
}

\section{Presencia, distribución y niveles de contaminación de plomo en el sedimentos superficiales de la Ría de Ferrol (NO de España)}

\author{
Ricardo Prego ${ }^{1 *}$ \\ Antonio Cobelo-García ${ }^{1}$ \\ Carmen Tubío ${ }^{1}$ \\ $\mathrm{M}^{\mathrm{a}}$ del Carmen Barciela ${ }^{2}$ \\ ${ }^{1}$ Marine Biogeochemistry Research Group \\ Instituto de Investigaciones Marinas (CSIC), Spain \\ *E-mail: prego@iim.csic.es \\ ${ }^{2}$ Departamento de Química Analítica \\ Facultad de Química \\ Universidad de Santiago de Compostela, Spain
}

Recibido en octubre de 2001; aceptado en octubre de 2002

\begin{abstract}
This article discuss, using sediment samples from the Ria of Ferrol, the need for a better understanding of the biogeochemical cycle of lead in the Galician rias which, until now, was based on differing methodologies mainly applied to the biota in only few areas of the most important rias from a socio-economic point of view. Thirty-five samples of superficial sediment were analysed for lead (in the $<63 \mu \mathrm{m}$ and total fractions) and opal percentage and organic carbon in the total. An analytical method is proposed employing ETAAS, whereby the sediment is introduced directly as a slurry together with the optimised amount of chemical modifiers. The accuracy of the method was checked by means of a certified reference material, obtaining a sensitivity of $2.72 \mu \mathrm{g} \mathrm{g}^{-1} \mathrm{~Pb}$ with an RSD of $5.9 \%$.

Values of lead in the superficial sediment of the Ria of Ferrol ranged from 13.5 to $159.1 \mu \mathrm{g} \mathrm{g}^{-1}$ for the fraction $<63 \mu \mathrm{m}$, and from 12.1 to $142.5 \mu \mathrm{g} \mathrm{g}^{-1}$ for the total fraction. The distribution does not follow a decreasing trend from the innermost part of the ria, as may have been expected, but rather the maximum values were found in the vicinity of the harbour area in the middle ria, indicating that rias behave as a lead deposition barrier avoiding the export of the metal to the open sea. Lead dispersion is mainly controlled by the tidal currents, given its lowest concentrations in the zones of strongest current, and also by the plankton, following the relationship obtained $[\mathrm{Pb}]=48$ [opal] +16 . A baseline lead concentration of $18.2 \mu \mathrm{g} \mathrm{g}^{-1}$ was obtained for the fraction $<63 \mu \mathrm{m}$ using core samples dated at $3745 \pm 70$ years before present. Applying this background values, the lead enrichment in the Ria of Ferrol is classified from moderate to considerable.
\end{abstract}

Key words: lead, contamination, sediment, ria, Galicia.

\section{Resumen}

El artículo aborda, a partir del sedimento de la Ría de Ferrol, la necesidad de un mayor conocimiento del ciclo biogeoquímico del plomo en las rías gallegas, basado hasta este momento en metodologías dispares aplicadas primordialmente a la biota en zonas puntuales de las rías más importantes socioeconómicamente. Se partió de 35 muestras de sedimento superficial, en cuya fracción total se analizaron la concentración de plomo, los porcentajes de ópalo y el carbono orgánico, mientras que en la fracción $<63 \mu \mathrm{m}$ sólo se midió el plomo. Para estas muestras se propuso un procedimiento analítico basado en la espectrometría de absorción atómica con atomización en cámara de grafito, donde el sedimento en forma de suspensión se introdujo directamente junto con la cantidad optimizada de modificadores químicos. La exactitud del método se verificó mediante el uso de un material de referencia, obteniéndose una sensibilidad de $2.72 \mu \mathrm{g} \mathrm{g}^{-1}$ de $\mathrm{Pb}$ y una precisión de RSD $5.9 \%$. Los valores medidos para el plomo en el sedimento superficial de la Ría de Ferrol se encontraron entre 13.5 y $159.1 \mu \mathrm{g} \mathrm{g}^{-1}$ para la fracción menor de $63 \mu \mathrm{m}$ y de 12.1 a $142.5 \mu \mathrm{g} \mathrm{g}^{-1}$ para la total. La distribución no sigue en patrón decreciente desde el fondo de la ría, como era de esperar, sino que tiene su máximo en el área portuaria situada en la parte media de la ría, indicando que las rías deben actúar como una barrera de deposición de plomo. En la dispersión de este metal intervienen principalmente la marea, dada su menor concentración 
en zonas de mayor corriente, y el plancton, por la relación: $[\mathrm{Pb}]=48$ [ópalo] +16 . Se ha cuantificado un valor de fondo de 18.2 $\mu \mathrm{g} \mathrm{g}^{-1}$ de $\mathrm{Pb}$ para la fracción sedimentaria $<63 \mu \mathrm{m}$ con muestras fechadas con $3745 \pm 70$ años de antigüedad. Aplicando éste, los factores de enriqueciminento para la Ría de Ferrol permiten clasificar su contaminación por plomo entre moderada y considerable

Palabras clave: plomo, contaminación, sedimento, ría, Galicia.

\section{Introduction}

Lead is present in nature at low concentrations except for localized areas generally under anthropogenic influence. The important increase in lead consumption since 1945 (Metallstatistik, 1988) has affected the coastal systems, where this metal is dumped from industries settled along the coastline and transported by continental waters (Gordeev, 1986) and the atmosphere (Chow, 1978). This has lead to an increase in the flux of this element to the environment around 20 times higher than two centuries ago (Murozumi et al., 1969) and to an important change in the biogeochemical cycle of lead in an important number of coastal systems (Nriagu, 1978; Branica and Konrad, 1980). The sources of estuarine contamination come from both organometallic compounds in leaded gasolines and from inorganic lead species, mainly as a result of petroleum and coal combustion, batteries and chemical pigments (Robinson, 1978). The most important inorganic lead species is the $\mathrm{Pb}(\mathrm{II})$ cation that forms insoluble oxides and sulphates, and precipitates as sulfur compounds in organic-rich areas, such as the Galician rias (Prego, 1993). The importance of lead in the marine environment is due to its high toxicity (Taylor, 1981) because small amounts of this metal may cause important alterations in marine organisms, which can become chronic (USEPA, 1980). For several decades this potential danger has driven important scientific work regarding lead and the ways to control it in the environment (GESAMP, 1985).

The studies on lead in the Galician coast began 40 years ago; however, following the review by Prego and CobeloGarcía (2003), around 30 papers are only available up till now about this metal. The presence of lead in the biota has focused special interest due to the exceptional conditions of the rias for aquaculture (Prego, 1995). The research carried out has been mainly restricted to the biggest and most important rias from the socioeconomic point of view (Prego and Cobelo-García, 2003). Therefore a substantial better knowledge of lead distribution in the rias is required, namely normalization of sampling and the fractions studied, unification or intercalibration of the methods so the results can be comparable and, finally, focus on the sedimentary biogeochemical compartment to asses its contamination state.

The Ria of Ferrol is a good example for applying the aforementioned because this ria was previously studied, mainly regarding its biological characteristics (Lueiro and Prego, 1999) and, although an environmental awareness already existed before 1988, little work had been carried out (table 1). It was after 1993 and, more recently, during the 1997-1999 period when the state of contamination of the Ria of Ferrol was considered, mainly due to the catastrophe originated by the

\section{Introducción}

El plomo es un elemento que se encuentra en la naturaleza en concentraciones bajas, excepto en áreas localizadas debidas normalmente a la influencia antropogénica. El gran incremento en el consumo de este metal a partir de 1945 (Metallstatistik, 1988) es lo que ha llegado a afectar al medio costero, hacia donde es vertido por industrias emplazadas en el litoral y transportado por las aguas continentales (Gordeev, 1986) y la atmósfera (Chow, 1978). Ello ha significado un incremento en un flujo de plomo hacia el medio natural unas veinte veces superior al de hace dos siglos (Murozumi et al., 1969) y un cambio notable en su ciclo biogeoquímico en muchos sistemas costeros (Nriagu, 1978; Branica y Konrad, 1980). La contaminación estuárica proviene tanto de la presencia organometálica del plomo en antidetonantes para gasolinas, como de compuestos inorganicos resultantes de la combustión de carbones y petróleos, y de baterías y pigmentos químicos, primordialmente (Robinson, 1978). En este último caso, la especie inorgánica más abundante es el catión $\mathrm{Pb}$ (II) que forma óxidos y sulfatos insolubles y precipita como sulfuro en zonas ricas en materia orgánica como las rías gallegas (Prego, 1993). La importancia del plomo en el ambiente marino radica en su elevada toxicidad (Taylor, 1981), ya que su presencia en pequeñas cantidades provoca alteraciones importantes en los organismos marinos, las cuales pueden llegar a ser crónicas (USEPA, 1980). Esa peligrosidad ha atraido el estudio del plomo y su control en el medio ambiente desde hace tiempo (GESAMP, 1985).

La atención sobre el plomo en la costa gallega comenzó hace 40 años, sin embargo, según la reciente revisión hecha por Prego y Cobelo-García (2003), sólo hay una treintena de publicaciones con alguna referencia a este metal pesado. En ellas se presta principal atención a la presencia de plomo en la biota por las condiciones excepcionales de las rías para el cultivo marino (Prego, 1995). Dichas investigaciones son, además, muy locales pues se centran en determinadas zonas de las rías mayores y más importantes socioeconómicamente (Prego y Cobelo-García, 2003). De ahí que sea necesaria una sustancial mejora en el conocimiento básico de la distribución de plomo en las rías, esto es, una normalización de los muestreos y de la fracción a estudiar, la unificación o intercalibración de métodos para poder comparar resultados $\mathrm{y}$, finalmente, centrarse en el compartimento biogeoquímico del sedimento para el conocimiento inicial del estado de la contaminación.

La Ría de Ferrol es un buen ejemplo para aplicar lo anteriormente comentado ya que corresponde a un área investigada principalmente en aspectos biológicos (Lueiro y Prego, 1999); aunque existió una preocupación ambiental antes de 1988, poca labor se llevó a cabo después (tabla 1). No ha sido hasta 
Prego et al:: Lead levels in the sediments of the Ria of Ferrol

Table 1. Lead concentrations in surface sediments of the Ria of Ferrol.

Tabla 1. Concentraciones de plomo en el sedimento superficial de la Ría de Ferrol.

\begin{tabular}{cccccc}
\hline $\begin{array}{c}\mathrm{N}^{\mathrm{o}} \text { of sampling } \\
\text { points }\end{array}$ & $\begin{array}{c}\text { Fraction } \\
(\mu \mathrm{m})\end{array}$ & $\begin{array}{c}\text { Concentration } \\
\text { range }\left(\mu \mathrm{g} \mathrm{g}^{-1}\right)\end{array}$ & Digestion procedure & Analysis & Reference \\
\hline 17 & $<2000$ (ria) & $24-162$ & $10 \mathrm{~g}+25 \mathrm{~mL} \mathrm{HNO}_{3}: \mathrm{HCl}(1: 3) ; 2 \mathrm{~h}, 50^{\circ} \mathrm{C}$ & AAS & Barreiro et al, 1988 \\
1 & $<63$ (subtidal) & 82 & $1 \mathrm{~g}+4 \mathrm{~mL} \mathrm{HNO}_{3} ; 120^{\circ} \mathrm{C}, 5 \mathrm{~h}$ & FAAS & Guerrero et al., 1988 \\
5 & $<63$ (intertidal) & $75-172$ & $0.5 \mathrm{~g}+15 \mathrm{~mL} \mathrm{HNO}_{3}: \mathrm{HF}(2: 1) ;$ microwave & FAAS & Carballeira et al., 1997 \\
5 & $<50$ (intertidal) & $40-118$ & $10 \mathrm{~g}+25 \mathrm{~mL} \mathrm{HNO}_{3}: \mathrm{HCl}(1: 3) ; 2 \mathrm{~h}, 50^{\circ} \mathrm{C}$ & AAS & Barreiro et al., 1988 \\
35 & $<2000$ (ria) & $12-143$ & (direct slurry sample injection) & ETAAS & This article \\
35 & $<63$ (ria) & $14-159$ & (direct slurry sample injection) & ETAAS & This article \\
\hline
\end{tabular}

sinking of the Aegean Sea tanker in the neighboring Ártabro Gulf (Ros, 1996).

This paper aims, in the one hand, to contribute to the general knowledge of the biogeochemical cycle of lead in estuaries, particularly in rias for which there is an important lack of information and, on the other hand, to show a procedure for the treatment of sediment samples in the Galician coast and to evaluate, for the first time in the Ria of Ferrol, the presence of lead.

\section{Study area}

The Ria of Ferrol (fig. 1) shows the typical extension for the Rias Altas, that is, those rias located north of the Finisterre Cape: $15 \mathrm{~km}$ long and a $21-\mathrm{km}^{2}$ area. This ria was classified by Torre-Enciso (1958) among the "funnel type" rias, since it corresponds to the low catchment area of a river flooded by the sea, in which fluvial erosion plays a major role whereas the lithological and tectonic factors are less important. The sediment contained in the ria basin is of continental and marine origin, the latter derived from the abundant biological activity in its waters (Lueiro and Prego, 1999). The granulometric plots show a predominance of fine sands in the mouth and the channel of the ria, poor in organic matter (1.7-2.5\%), whereas in the rest of the ria there is fine mud with organic content ranging from 3.7 to $13.2 \%$ (López-Jamar et al., 1996).

The main fluvial input to the Ria of Ferrol is the Grande de Xubia River, flowing into the ria head with a mean annual flow of $5.5 \mathrm{~m}^{3} \mathrm{~s}^{-1}$ (Río and Rodríguez, 1992) with the typical fluctuations of an oceanic rain pattern (Soto and Díaz-Fierros, 1996). This small continental input is the main drive of the positive estuarine residual circulation that is generally observed in this ria (Varela et al., 1996), which is controlled by the tidal currents.

The anthropogenic activities (IGE, 1995) and most of the industrial and urban influence is located in the middle-inner part of the ria, where not only most of the population is concentrated (143,000 inhabitants) but also the important industrial activity including shipyards, iron and steel industries and a commercial port with a mean annual vessel traffic around $1,500,000$ gross register tons (IDASA, 1987).
1993 y, más recientemente, en 1997-99, cuando se han abordado temas muy concretos sobre la contaminación general en la Ría de Ferrol, impulsados en buena parte por la catástrofe originada por el hundimiento del petrolero Aegean Sea en el vecino Golfo Ártabro (Ros, 1996).

El presente artículo pretende, por una parte, contribuir al conocimiento general del ciclo biogeoquímico del plomo en estuarios, muy carente de datos sobre rías, y por otra parte, ofrecer un procedimiento guía para el tratamiento de las muestras de sedimento en la costa gallega, a la vez que evaluar por primera vez para la Ría de Ferrol la importancia de la presencia de plomo en su cuenca.

\section{Área de estudio}

La Ría de Ferrol (fig. 1) tiene $15 \mathrm{~km}$ de longitud y $21 \mathrm{~km}^{2}$ de superficie, dimensiones semejantes a las de otras Rías Altas, esto es, de las situadas al norte del Cabo Finisterre. Dicha ría se ha clasificado dentro del grupo de "rías en embudo" (TorreEnciso, 1958), pues corresponde al tramo inferior de un río inundado por el mar, con un papel predominante de la acción erosiva fluvial y secundario de los factores litológico y tectónico. El sedimento contenido en la cuenca de la ría es de origen continental y marino, este último derivado de la abundante actividad biológica en sus aguas (Lueiro y Prego, 1999). Las curvas granulométricas indican para su boca y canal un predominio de arena fina, pobre en materia orgánica (1.7$2.5 \%$ ), mientras que en el resto de la ría existe un fango fino de contenido organico entre 3.7 y $13.2 \%$ (López-Jamar et al., 1996).

El principal curso fluvial hacia la Ría de Ferrol es el Río Grande de Xubia que vierte en su cabecera un caudal medio anual de $5.5 \mathrm{~m}^{3} \mathrm{~s}^{-1}$ (Río y Rodríguez, 1992) con oscilaciones características de un régimen pluvial oceánico (Soto y DíazFierros, 1996). Este pequeño aporte continental es el principal motor de la circulación residual estuárica que suele observarse en esta ría (Varela et al., 1996) dominada por el flujo mareal.

La actividad humana (IGE, 1995) y la mayor influencia antropogénica sobre la ría se desarrollan en la zona mediainterna donde no sólo se concentra la mayor parte de su población (143,000 habitantes), sino que también existe una 


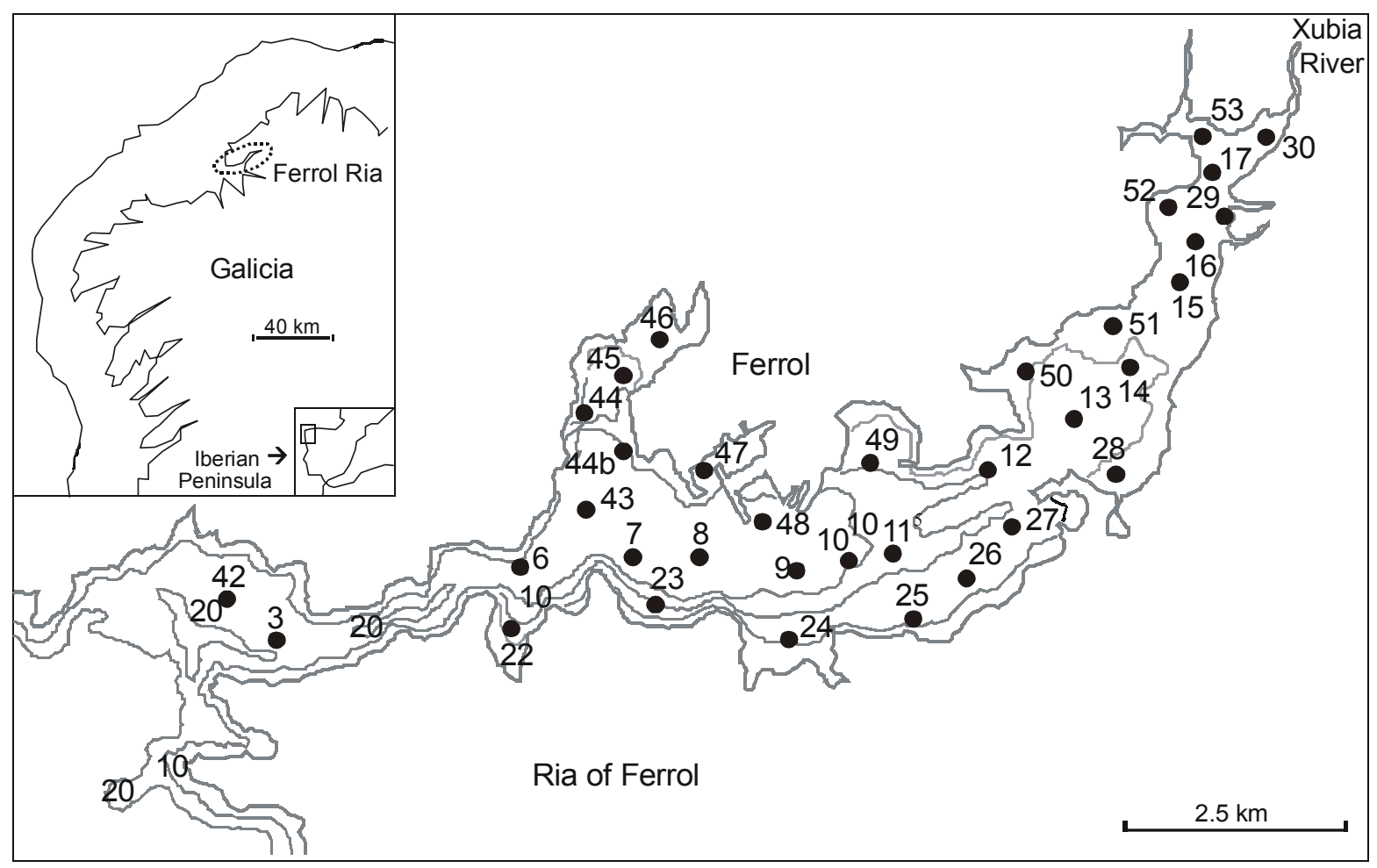

Figure 1. Bathymetry chart of the Ria of Ferrol and surface sediment sampling stations.

Figura 1. Mapa batimétrico de la Ría de Ferrol y situación de las estaciones donde se extrajeron muestras de sedimento superficial.

\section{Material and methods}

The sediment samples were taken from the R/V Mitylus and its auxiliary boat Zoea at the sampling stations shown in figure 1, using two Van Veen grabs of different size. From the collected sediment only the 1 -cm-thick surface layer was taken, using a polyethylene spatula, and stored in polyethylene vials hermetically closed (previously acid-washed using $10 \%$ nitric acid for $24 \mathrm{~h}$ and rinsed with Milli-Q ultrapure water) and were left at $4^{\circ} \mathrm{C}$ in a fridge pending drying. The sediment, dried-up using an oven at a temperature lower than $50^{\circ} \mathrm{C}$, was fractioned by means of plastic sieves with 2000 and $63-\mu \mathrm{m}$ nylon meshes. The different fractions were stored in plastic tubes (pre-cleaned using the same procedure as for the vials) until analysis. Analysis was carried out in the $<63-\mu \mathrm{m}$ fraction and the sediment size fraction between 63 and $2000 \mu \mathrm{m}$. The metal concentration in the total fraction was calculated using the percent of every size fraction obtained by weighing the sieved sediment.

The determination of lead in the samples was carried out by means of atomic absorption spectroscopy with electrothermal atomization (ET-AAS) using a Varian 220 device equipped with Zeeman background correction; the source of radiation was a hollow cathode lamp operating at $10 \mathrm{~mA}$; the wavelength used was $283.3 \mathrm{~nm}$ and a slit of $0.5 \mathrm{~nm}$. Pirolitic graphite tubes with L'vov platform were used for the sample atomization. The absorbance measurements were done using the peak area with a 3-s integration time. importante actividad industrial, principalmente astilleros, siderurgia y un puerto comercial con un tráfico de buques en torno a las 1,500,000 TRB anual (IDASA, 1987).

\section{Material y métodos}

Las muestras de sedimento fueron recogidas desde el B/O Mytilus y su embarcación auxiliar Zoea en las estaciones de muestreo señaladas en la figura 1, mediante dos dragas tipo cuchara (Van Veen) de diferente tamaño. Del material extraído se tomaron muestras únicamente de la capa superficial de $1 \mathrm{~cm}$ de espesor con una espátula de polietileno, las cuales se guardaron en viales del mismo material, herméticamente cerrados (previamente lavados con ácido nítrico al 10\%, durante $24 \mathrm{~h} \mathrm{y}$ enjuagados con agua Milli-Q) y se almacenaron en una nevera a $4^{\circ} \mathrm{C}$ hasta el momento de su secado. El sedimento seco (en estufa a una temperatura inferior a $50^{\circ} \mathrm{C}$ ) fue fraccionado mediante tamices de plástico con malla de nylon de 2000 y 63 $\mu \mathrm{m}$ de paso de luz. Las distintas fracciones se guardaron en tubos de plástico (pretratados como los viales) hasta su análisis, efectuándose éste para la fracción menor de $63 \mu \mathrm{m}$ y para la comprendida entre 63 y $2000 \mu \mathrm{m}$. Posteriormente se calculó la concentración metálica en la fracción total, tras considerar los porcentajes de cada una de las fracciones parciales, estimados por pesada del sedimento tamizado.

La determinación del plomo en las muestras se llevó a cabo mediante espectrometría de absorción atómica con 
In order to avoid sample contamination and analyte loss due to volatilization or to retention in insoluble materials associated with the digestion procedures, sediment slurries were prepared as sample pre-treatment. This procedure avoids the sample digestion and considerably reduces the time required for the analysis. The slurries were prepared using the method proposed by Bermejo Barrera et al. (1994): a 0.1-g aliquot of of sediment $<63-\mu \mathrm{m}$ grain size is weighed and put in a polyethylene vial together with $5 \mathrm{~g}$ of zirconium pearls and $3 \mathrm{~mL}$ Milli-Q ultrapure water. The content of the vial is homogenized using a Vibromatic shaker for $60 \mathrm{~min}$; then the zirconium pearls are removed by means of a porcelain sieving funnel. Finally, the slurry obtained is made up to $10 \mathrm{~mL}$ and stored at $4^{\circ} \mathrm{C}$ pending analysis. For the sediment fraction $>63 \mu \mathrm{m}$, after ground in an agate mortar, the same procedure was applied.

For every sample two slurries were prepared and two analyses were carried out for each slurry, i.e., four analyses were done per sample. If the results differed more than $5 \%$, a third slurry was prepared and two more analyses were carried out.

Just before the analysis, Titron X-100 (0.1\%) was added to a sample slurry aliquot as an stabilizing agent, together with the magnesium nitrate and palladium required as chemical modifiers. The optimum measurement conditions and the modifiers' concentrations required, $2 \mu \mathrm{g} \mathrm{mL}^{-1} \mathrm{Pd}$ and $15 \mu \mathrm{g} \mathrm{mL}^{-1}$ $\mathrm{Mg}\left(\mathrm{NO}_{3}\right)_{2}$, were previously optimized and adapted to the device used and the type of sediment analyzed. The optimized temperature program is indicated in table 2 . The sample volume spiked into the graphite tube was $20 \mu \mathrm{L}$.

The accuracy of the analytical procedure was checked using a certified reference material (PACS- 1 of the National Research Council of Canada; $\left.[\mathrm{Pb}]=404 \pm 20 \mu \mathrm{g} \mathrm{g}^{-1}\right)$. The results obtained, $409 \pm 24 \mu \mathrm{g} \mathrm{g}^{-1}$, agree well with the certified values, showing the accuracy of the measurements carried out. Sensitivity of the analytical procedure was checked as well, calculating the detection limit for 10 determinations of a slurry blank sample, being this $2.72 \mu \mathrm{g} \mathrm{g}^{-1}$ of $\mathrm{Pb}$. The precision of the method (RSD 5.9\%) was also checked, by means of calibration with aqueous standards.

The determination of the amount of opal contained in the surface sediments was carried out following the method of alkaline digestion by Mortlock and Froelich (1989) and the

Table 2. Graphite furnace atomic absorption temperature programme. Tabla 2. Programa de temperaturas para el horno de grafito del equipo de absorción atómica.

\begin{tabular}{lcccc}
\hline Step & $\begin{array}{c}\text { Temperature } \\
\left({ }^{\circ} \mathrm{C}\right)\end{array}$ & $\begin{array}{c}\text { Ramp } \\
(\mathrm{s})\end{array}$ & $\begin{array}{c}\text { Permanence } \\
(\mathrm{s})\end{array}$ & $\begin{array}{c}\text { Argon flux } \\
\left(\mathrm{L} \mathrm{min}^{-1}\right)\end{array}$ \\
\hline Drying & 100 & 30 & 40 & 3 \\
Mineralisation & 800 & 10 & 11 & 3 \\
Atomisation & 2300 & 0.7 & $($ meas. $)$ & 0 \\
Cleaning & 2400 & 0 & 2 & 3 \\
Cooling & 40 & 30 & 0 & 3 \\
\hline
\end{tabular}

atomización electrotérmica (ETAAS) en un equipo Varian modelo 220 dotado con corrección de fondo Zeeman; la fuente de radiación fue una lámpara de cátodo hueco que opera a una intensidad de corriente de $10 \mathrm{~mA}$; la longitud de onda seleccionada, $283.3 \mathrm{~nm}$ y la rendija $0.5 \mathrm{~nm}$. Para la atomización se usaron tubos de grafito pirolíticos con plataforma L'vov. Las medidas de absorbancia se realizaron en área de pico para un tiempo de integración de $3 \mathrm{~s}$.

A fin de reducir el riesgo de contaminación de la muestra o la pérdida de analito por volatilización o por retención en materiales insolubles, asociados a la técnica de digestión, se eligió como etapa previa hacer suspensiones con el sedimento. Así se evitó el proceso de digestión en el pretratamiento de la muestra y también se redujo considerablemente el tiempo de análisis. Las suspensiones se prepararon partiendo del método propuesto por Bermejo Barrera et al. (1994). Una alícuota de $0.1 \mathrm{~g}$ de sedimento, de tamaño de partícula inferior a $63 \mu \mathrm{m}$ se pesó y se colocó en un vial de polietileno junto con $5 \mathrm{~g}$ de perlas de zirconio y $3 \mathrm{ml}$ de agua Milli-Q. El contenido del vial se homogeneizó en un agitador Vibromatic durante $60 \mathrm{~min}$, al cabo de los cuales las perlas de zirconio fueron separadas mediante un embudo tamizador de porcelana. Por último, la suspensión obtenida fue llevada a un volumen final de $10 \mathrm{ml}$ y guardada a $4^{\circ} \mathrm{C}$ hasta el momento de su análisis. La fracción de sedimento mayor de $63 \mu \mathrm{m}$ recibió el mismo tratamiento, previo molido de la misma en un mortero de ágata.

Para cada muestra de sedimento se prepararon dos suspensiones, y de cada una de ellas se hicieron dos medidas, con un total de cuatro análisis por muestra. En los casos en que los resultados difirieron entre sí más de un $5 \%$, se preparó una tercera suspensión y se hicieron dos análisis más.

Justo antes del análisis se tomó una alícuota de la muestra en suspensión y se le añadió Triton X-100 (0.1\%) como agente estabilizador, junto con la cantidad necesaria de paladio y nitrato de magnesio como modificadores químicos. Las condiciones de medida, así como las concentraciones requeridas de los modificadores, $2 \mu \mathrm{g} \mathrm{mL}{ }^{-1} \mathrm{Pd}$ y $15 \mu \mathrm{g} \mathrm{mL}^{-1} \mathrm{Mg}\left(\mathrm{NO}_{3}\right)_{2}$, debieron ser optimizadas y adecuadas a las características del equipo usado y del sedimento analizado. El programa de temperaturas optimizado aparece recogido en la tabla 2. El volumen de muestra inyectado fue de $20 \mu \mathrm{L}$.

La exactitud del método de análisis empleado se verificó mediante el uso de un material de referencia (PACS-1 del National Research Council de Canadá), cuyo contenido en plomo es de $404 \pm 20 \mu \mathrm{g} \mathrm{g}^{-1}$. Los resultados obtenidos, $409 \pm$ $24 \mu \mathrm{g} \mathrm{g}^{-1}$, están de acuerdo con el valor certificado y aseguran la exactitud de las medidas. Asimismo se estudió la sensibilidad calculando el límite de detección para 10 determinaciones de un blanco de suspensión, siendo éste de $2.72 \mu \mathrm{g} \mathrm{g}^{-1} \mathrm{de} \mathrm{Pb}$. Por último, se verificó la precisión del método por medio de la calibración con patrones acuosos, siendo ésta satisfactoria (RSD 5.9\%).

La determinación del porcentaje de ópalo contenido en el sedimento superficial se realizó siguiendo el proceso de 
following analysis of dissolved silicate in the obtained extract using the method reported by Hansen and Grasshoff (1983).

The organic carbon content in the surface sediments was determined by the difference between total carbon -measured in a Perkin Elmer elemental $\mathrm{CNH}$ analyzer- and inorganic carbon -analyzed by calcination loss between 550 and 975-. The Unidad de Servicios Generales de Apoyo a la Investigación at the Universidad de La Coruña carried out these organic carbon analyses.

\section{Results and discussion}

The lead concentration found in the surface sediment of the Ria of Ferrol ranged from 13.5 to $159.1 \mu \mathrm{g} \mathrm{g}^{-1}$ in the fine $(<63$ $\mu \mathrm{m}$ ) fraction (fig. 2) and from 12.1 to $142.5 \mu \mathrm{g} \mathrm{g}^{-1}$ in the total fraction (fig. 3). The scarce data previously reported (table 1) lie within this range, excep for those belonging to intertidal areas, which are slightly higher. In comparison with the values found in other Galician rias, reaching $\mathrm{Pb}$ concentrations sometimes higher than $400 \mu^{g^{-1}}$ (Prego and Cobelo-García, 2003), lead concentrations excessively high are not observed in the Ria of Ferrol. The concentrations are more similar to the values found in oceanic basins (8-60 $\mu \mathrm{g} \mathrm{g}^{-1}$; Nriagu, 1978) than to those reported for estuaries under a strong anthropogenic influence where lead concentrations up to $1450 \mu \mathrm{g} \mathrm{g}^{-1}$ were found in harbor sediments (Standford et al., 1981). digestión alcalina descrito por Mortlock y Froelich (1989) y el posterior análisis del silicato disuelto según Hansen y Grasshoff (1983) en el extracto obtenido.

El contenido de carbono orgánico en el sedimento superficial fue determinado por la Unidad de Servicios Generales de Apoyo a la Investigación de la Universidad de La Coruña como la diferencia entre el carbono total, medido en un analizador elemental CNH Perkin-Elmer, y el carbono inorgánico, por pérdida de peso tras calcinación entre 550 y $975^{\circ} \mathrm{C}$.

\section{Resultados y discusión}

Los valores medidos para el plomo en el sedimento superficial de la Ría de Ferrol se encontraron entre 13.5 y $159.1 \mu \mathrm{g} \mathrm{g}^{-1}$ para la fracción menor de $63 \mu \mathrm{m}$ (fig. 2) y de 12.1 a $142.5 \mu \mathrm{g} \mathrm{g}^{-1}$ para la total (fig. 3). Los pocos datos obtenidos con anterioridad (tabla 1) se hallan dentro de este rango, salvo los correspondientes a la zona intermareal que son ligeramente más altos. En la Ría de Ferrol no se observa ninguna concentración exageradamente alta de plomo en comparación con los resultados puntuales existentes en otras rías, los cuales llegan a ser superiores a $400 \mu \mathrm{g} \mathrm{g}^{-1}$ de $\mathrm{Pb}$ (Prego y Cobelo-García, 2003). Su sedimento es más similar al contenido en las cuencas oceánicas (8-60 $\mu \mathrm{g} \mathrm{g}^{-1}$ de $\mathrm{Pb}$; Nriagu, 1978) que al de estuarios bajo una fuerte influencia antropogénica donde en sedimentos portuarios se han llegado a encontrar valores que alcanzan los $1450 \mu \mathrm{g} \mathrm{g}^{-1} \mathrm{de} \mathrm{Pb}$ (Standford et al., 1981).

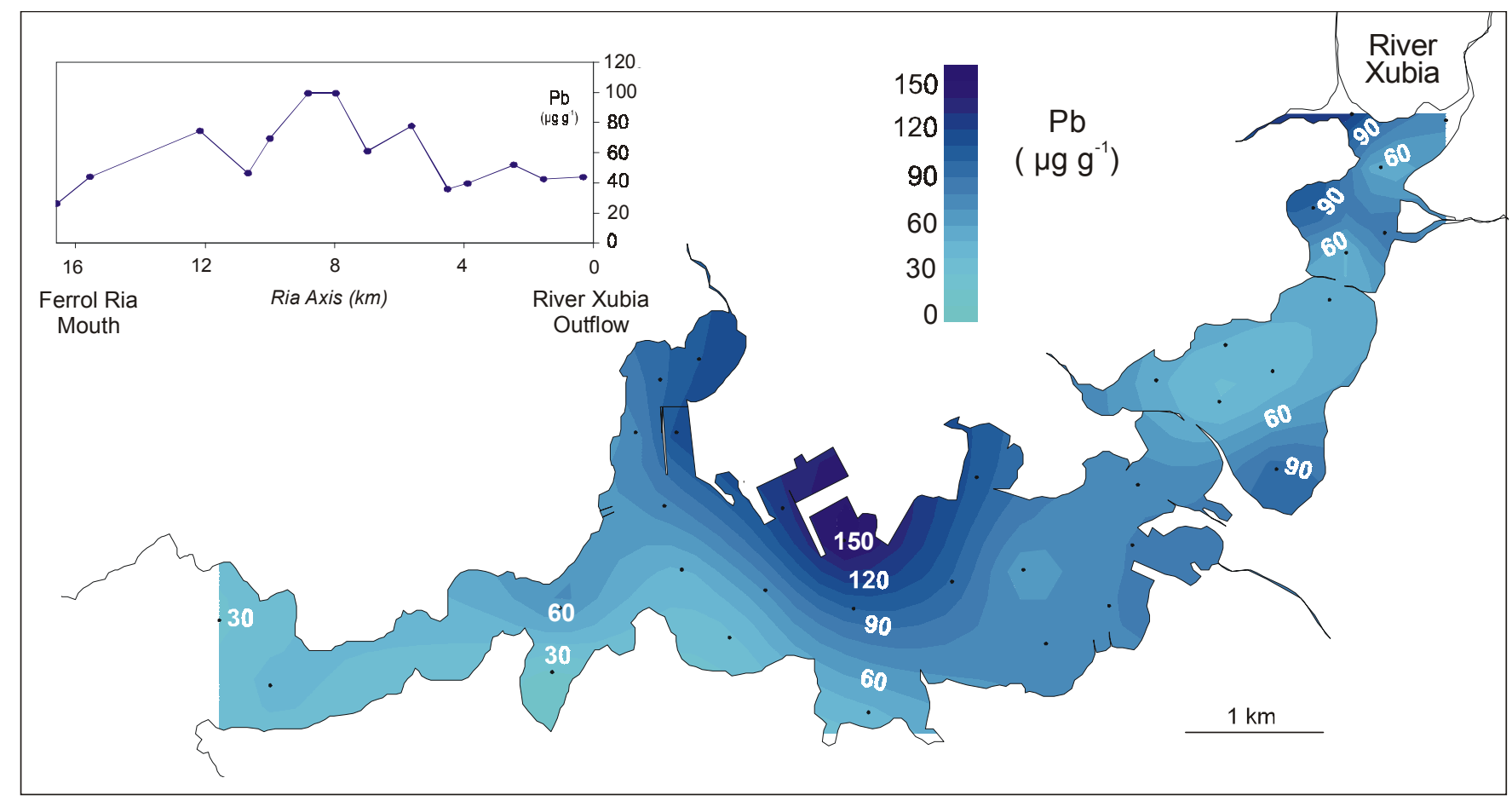

Figure 2. Lead concentration map of the surface sediment fraction $<63 \mu \mathrm{m}$ in the Ria of Ferrol and its axial variation.

Figura 2. Mapa de la distribución de plomo para la fracción inferior a $63 \mu \mathrm{m}$ del sedimento superficial en la Ría de Ferrol y variación a lo largo de su eje. 
In order to define the importance of the metallic contaminants it has to be considered that the high degree of water exchange in the rias (Prego and Fraga, 1992) reduces the interest of using data of dissolved $\mathrm{Pb}$ in the water column. Sediments, due to their inherent temporal stability and higher contamination levels - because of the metal accumulation-, are more appropriate to evaluate the state of heavy metals in the rias (Carballeira et al., 1997). The marked adsorbing and transport capacities of the the fine fraction $(<63 \mu \mathrm{m})$ related to metallic traces allow a good comparison of the values obtained for the sediments of the Galician coast (Guerrero et al., 1988; Carral et al., 1995); moreover, the data available for the fraction smaller than $2 \mu \mathrm{m}$ or $63 \mu \mathrm{m}$ in Galician estuaries do not show any perceptible differences in the lead concentrations (Belzunce et al., 1997a). As a consequence, the use of the fraction $<63 \mu \mathrm{m}$ is advisable as a start point to discuss the lead concentration levels in the Ria of Ferrol, and also to contrast their situation with other estuaries (Försner, 1980).

Therefore, in the present paper the fraction $<63 \mu \mathrm{m}$ was chosen as a reference. Nevertheless, when comparing the results obtained for this fine fraction with the total fraction (fig. 3), a straight line with a slope value near 1 (0.99) with a good correlation $(r=0.91)$ is obtained. This indicates that the use of both sedimentary fractions to study the lead concentration in the Ria of Ferrol would be correct and, furthermore, a different accumulation behavior of this metal is not likely with respect to the grain size in this ria.

\section{Lead distribution in the sediment}

The isoline map of lead concentration for the surface sediments in the Ria of Ferrol clearly indicates a maximum in the area surrounded by the harbor (150- $\mu \mathrm{g}-\mathrm{g}^{-1}$ isoline, fig. 2$)$ and two secondary maxima in the inner part of the ria $\left(90 \mu \mathrm{g} \mathrm{g}^{-1}\right.$, fig. 2). On the contrary, lead concentrations are lower in those

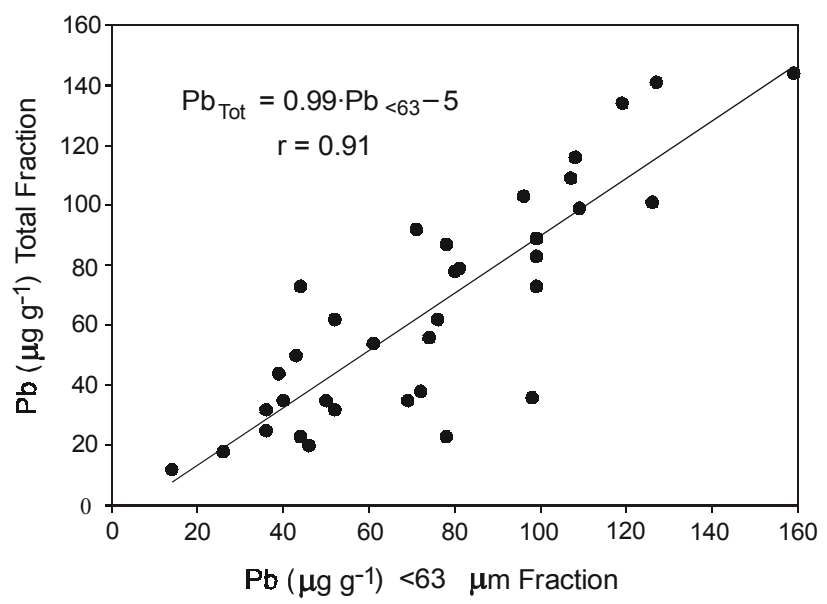

Figura 3. Lead concentration in the surface sediment of the Ria of Ferrol: total fraction $v s$. fraction $<63 \mu \mathrm{m}$.

Figura 3. Relación del contenido en plomo de la fracción inferior a $63 \mu \mathrm{m}$ respecto de la total.
Para definir la importancia de los contaminantes metálicos, es de considerar que el buen intercambio de agua en las rías (Prego y Fraga, 1992) resta interés al uso de datos de la columna de agua. Los sedimentos, al poseer una estabilidad temporal y niveles de contaminación más elevados, debidos a una acumulación metálica, son más adecuados para evaluar la presencia de metales pesados en las rías (Carballeira et al., 1997). El marcado poder adsorbente y de transporte que presentan las partículas de tamaño inferior a $63 \mu \mathrm{m}$ frente a trazas metálicas permite una buena comparación de los valores obtenidos para el sedimento en la costa gallega (Guerrero et al., 1988; Carral et al., 1995); además, los datos de que se dispone para las fracciones inferiores a $2 \mu \mathrm{m}$ ó $63 \mu \mathrm{m}$ en estuarios gallegos no manifiestan diferencias apreciables entre sus contenidos de plomo (Belzunce et al., 1997a). Así pues, es aconsejable tomar la fracción menor de $63 \mu \mathrm{m}$ como punto de partida para discutir los niveles de concentración de plomo en la Ría de Ferrol y también para poder comparar su situación con otros estuarios (Försner, 1980).

En consecuencia, la fracción del sedimento menor de 63 $\mu \mathrm{m}$ será la que se utilice como referencia en el presente artículo. No obstante, cuando se comparan los resultados obtenidos para dicha fracción con la total se obtiene (fig. 3) una recta de pendiente prácticamente uno (0.99), con un buen ajuste $(r=0.91)$ y un término independiente bajo. Ello indica que sería correcta la utilización de cualquiera de esas fracciones sedimentarias para definir la presencia de plomo en la Ría de Ferrol y, además, que no parece existir un comportamiento diferente en la captación de este metal pesado respecto del tamaño de la partícula en esta ría.

\section{Distribución de plomo en el sedimento}

El mapa de isolíneas de concentración de plomo para el sedimento superficial de la Ría de Ferrol indica de forma clara un máximo en el área portuaria (isolínea de $150 \mu \mathrm{g} \mathrm{g}^{-1}$ de $\mathrm{Pb}$; fig. 2) y dos zonas secundarias en la parte interna de la ría (90 $\mu \mathrm{g} \mathrm{g}^{-1}$ de $\mathrm{Pb}$, fig. 2). Por el contrario, la presencia de plomo es menor donde la corriente mareal es más fuerte: la parte interna próxima a un estrechamiento $\left(40 \mu \mathrm{g} \mathrm{g}^{-1} \mathrm{de} \mathrm{Pb}\right.$, fig. 2) y en la boca de la ría (30-40 $\mu \mathrm{g} \mathrm{g}^{-1} \mathrm{de} \mathrm{Pb}$, fig. 2). Esos valores se aproximan a los medidos en la misma fracción sedimentaria de la plataforma continental adyacente (21-33 $\mathrm{gg} \mathrm{g}^{-1}$; Guerrero et al., 1988).

Aunque se presupone un patrón interno-fluvial respecto a la riqueza metálica de plomo en el sedimento de las rías gallegas (Herbello y Prego, 1998), éste no se puede considerar como general. A pesar de que los datos previos obtenidos en sedimento intermareal también permitieran esa deducción para la Ría de Ferrol (Carballeira et al., 1997), según la distribución horizontal de plomo (fig. 2) existe una asimetría hacia la margen norte de su parte central, reflejo de los aportes de origen antropogénico. Algo semejante ocurre también en la Ría de Vigo en el área portuaría de su margen central-sur (>150 $\mathrm{g} \mathrm{g}^{-1}$ de $\mathrm{Pb}$; Besada et al., 1997; Belzunce et al., 
areas where tidal currents are stronger: the inner part in the vicinity of a channel (40 $\mu \mathrm{g} \mathrm{g}^{-1}$, fig. 2$)$ and in the mouth of the ria (30-40 $\mu \mathrm{g} \mathrm{g}^{-1}$, fig. 2). These values are close to those measured in the same sedimentary fraction for the neighboring continental shelf (21-33 $\mu \mathrm{g} \mathrm{g}^{-1}$; Guerrero et al., 1988).

Although an inner fluvial pattern is assumed for the lead concentrations in the Galician rias (see Herbello and Prego, 1998), this can not be taken as a general rule. Despite the previously reported data for intertidal sediments also pointed to the same assumption for the Ria of Ferrol (Carballeira et al., 1997), following the horizontal lead distribution (fig. 2) there is an asymmetry towards its northern margin in the middle part of the ria, which is a consequence of the anthropogenic inputs. Something similar was also reported for the Ria of Vigo in the harbor area located at the middle-southern margin (> $150 \mu \mathrm{g} \mathrm{g}^{-1}$; Besada et al., 1997; Belzunce et al., 2000), but in this ria lead values are even higher in its head (Belzunce et al., 1997b). Therefore, inside the rias as well as in other estuaries (Ewers and Schlipköter, 1991), most of the lead inputs generally occur directly from freshwater currents and this metal tends to be located in the surrounding area of discharge points, due to the low solubility of the lead compounds in seawater. Consequently rias, which are mixing areas of fresh and saline waters with high primary production and strong sedimentation, can be considered as sedimentation traps for lead, which accumulates in the vicinity of the discharge source points.

The physical factors participating on the dispersion of lead inside the Ria of Ferrol are controlled by the tidal circulation. The fact that lead concentration is not likely to depend on the sediment fraction (fig. 3) suggests that lower lead concentrations in several parts of this ria are caused by: (a) the "cleansing" of the sediment by the tidal current-transported water in the inner part of the ria; and (b) this along with a suspended particulate matter exchange with the shelf -which is poor in lead-in the mouth of the ria.

There are also other biogeochemical processes that take part, within which plankton plays an important role. The good correlation found between lead concentrations and percent of opal in the surface sediments $([\mathrm{Pb}]=48$ [ópalo] $+16 ; r=0.88)$ suggests that, particularly, diatoms can be a substantial mechanism in scavenging lead to the sediment. In this sense, the scattering of data obtained in the plot of lead versus organic carbon (fig. 4) does not indicate any correlation of lead with the urban and industrial organic matter but with the organic matter with a C:N ratio similar to a phytoplankton-rich sediment (fig. 4).

Diatoms can concentrate up to $47 \mu \mathrm{g} \mathrm{g}^{-1}$ of $\mathrm{Pb}$ (dry weight) in coastal areas (Martin and Knauer, 1973), and therefore can be good direct or indirect -by means of zooplankton faeces (Fowler, 1977; Reinfelder and Fisher, 1991)- pathways in scavenging lead to the sediments of the Ria of Ferrol.
2000), pero en esta ría la presencia de plomo es aún mayor en su cabecera (Belzunce et al., 1997b). En consecuencia, dentro de las rías, al igual que en otros estuarios (Ewers y Schlipköter, 1991), las mayores descargas de plomo suelen ocurrir directamente en los cursos de agua dulce y este metal tiende a localizarse cerca de los puntos de descarga por la baja solubilidad de los compuestos de plomo en contacto con el agua marina. Por ello, se puede considerar que las rías, lugares de mezcla de aguas dulces y marinas y áreas de gran producción y sedimentación, deben actúar como una barrera de deposición de plomo, el cual se acumula cerca de las zonas próximas a los puntos de vertido.

Los agente físicos que intervienen en la dispersión del plomo dentro de la Ría de Ferrol están dominados por la circulación mareal. La independencia citada del contenido en plomo respecto de la fracción del sedimento (fig. 3) hace pensar que las menores concentraciones de plomo en el sedimento de esta ría son causadas por: (a) el lavado del sedimento por el agua transportada en la corriente de marea para la parte interna de la
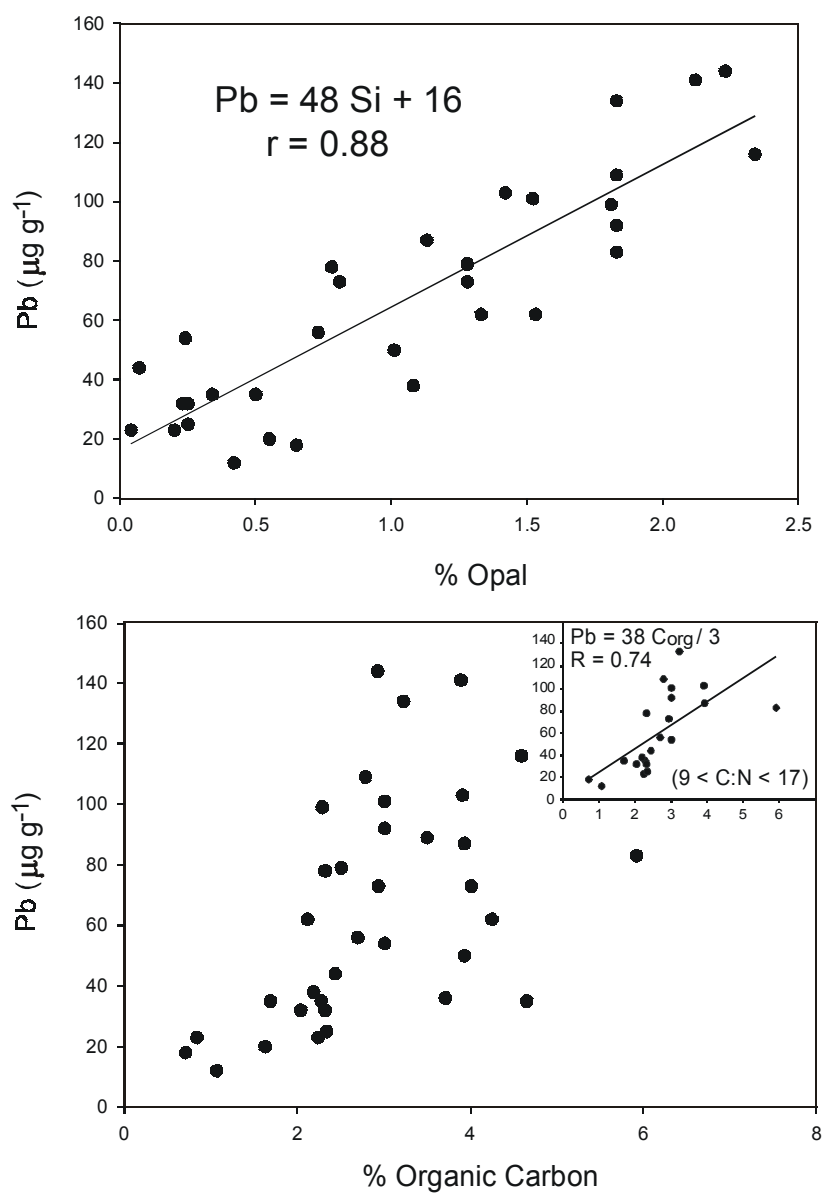

Figure 4. Lead concentration in surface sediments (fraction $<63 \mu \mathrm{m}$ ) vs. opal and organic carbon concentrations (total fraction) in the Ría of Ferrol.

Figura 4. Relación del contenido en plomo del sedimento superficial (fracción < $63 \mu \mathrm{m}$ ) respecto al contenido de ópalo y carbono orgánico (fracción total) en la Ría de Ferrol. 
Lead contamination in the ria

The lead concentrations in the fraction $<63 \mu \mathrm{m}$ and the corresponding background value were taken to ascertain the point sources of contamination in the ria. To this aim the enrichment factors (EFs) were calculated as the ratio between the concentration of the current sample and the background value.

The lead background values (BV) available to date for the Galician coast were estimated by modal analysis from intertidal surface sediment samples (Carral et al., 1995). Using this approach, BVs of $78 \mu \mathrm{g} \mathrm{g}^{-1}$, for rias of granitic lithology, and $50 \mu \mathrm{g} \mathrm{g}^{-1}$ for rias of schist-gneiss lithology were reported (Carral et al., 1995).

In order to calculate the EF in the Ria of Ferrol, the determination of BV taking pre-industrial values obtained from dated sediment cores was chosen. For this, it is usual to use as background reference value the oldest layers (Establier et al., 1985 ) and therefore the samples between 130- and 170-cm depth were collected from a core taken using a "vibro-corer" in the central part (in the vicinity of station 9, fig. 1). A background value (BV) of $18.2 \mu \mathrm{g} \mathrm{g}^{-1}$ was obtained, which corresponds to $3745 \pm 70$ years before present, calculated by ${ }^{14} \mathrm{C}$ dating at $161 \mathrm{~cm}$ depth (Santos and Vidal-Romaní, 2000).

This newly BV determined is lower than the previously reported for sediments of rias, and is closer to the value of 32 $\mu \mathrm{g} \mathrm{g}^{-1}$ for granites and $16 \mu \mathrm{g} \mathrm{g}^{-1}$ for schist-gneisses proposed by Wedepohl (1991) for world average sediments.

With this lead BV proposed for sediments of the Ria of Ferrol, the EFs shown in figure 5 were obtained. The contamination levels were determined according to the classification given by Hakanson (1980) for Swiss lakes: null $<1>$ moderate $<3>$ considerable $<6>$ very high . ría y (b) lo anterior, unido a un intercambio de particulas con la plataforma, pobres en plomo, para la boca de la ría.

También intervienen otros procesos biogeoquímicos en los que el plancton juega un papel importante. La correspondencia (fig. 4) obtenida entre las concentraciones de plomo y los porcentajes de ópalo en el sedimento superficial $([\mathrm{Pb}]=48$ [ópalo] $+16 ; r=0.88)$ sugieren que las diatomeas, en particular, pueden ser un mecanismo importante en el transporte de plomo hacia el sedimento. Asimismo, la dispersión de los puntos definidos por la concentración de plomo frente al porcentaje de carbono orgánico (fig. 4) no parecen asociar la coprecipitación de plomo con compuestos orgánicos de origen urbano y si con los que presentan una relación $\mathrm{C}: \mathrm{N}$ próxima a la de un sedimento rico en restos de fitoplancton (fig. 4).

Las diatomeas, que almacenan hasta $47 \mu \mathrm{g} \mathrm{g}^{-1} \mathrm{de} \mathrm{Pb}$ (peso seco) en regiones costeras (Martin y Knauer, 1973), pueden ser buenos medios directos, o indirectos a través de las heces fecales del zooplancton (Fowler, 1977; Reinfelder y Fisher, 1991), en el transporte de plomo hacia el sedimento de la Ría de Ferrol.

\section{Contaminación de la ría por plomo}

El contenido en plomo de la fracción del sedimento menor de $63 \mu \mathrm{m}$ y su nivel de fondo pueden tomarse como referencia para clasificar los focos de contaminación. Para ello se calculan los factores de enriquecimiento (EF) para el plomo como la concentración de la muestra dividida entre el nivel de fondo.

La información que actualmente existe sobre los niveles de fondo (BV) de plomo para la costa gallega parten de datos de sedimento superficial intermareal a los cuales se les ha aplicado un análisis modal (Carral et al., 1995). Se han

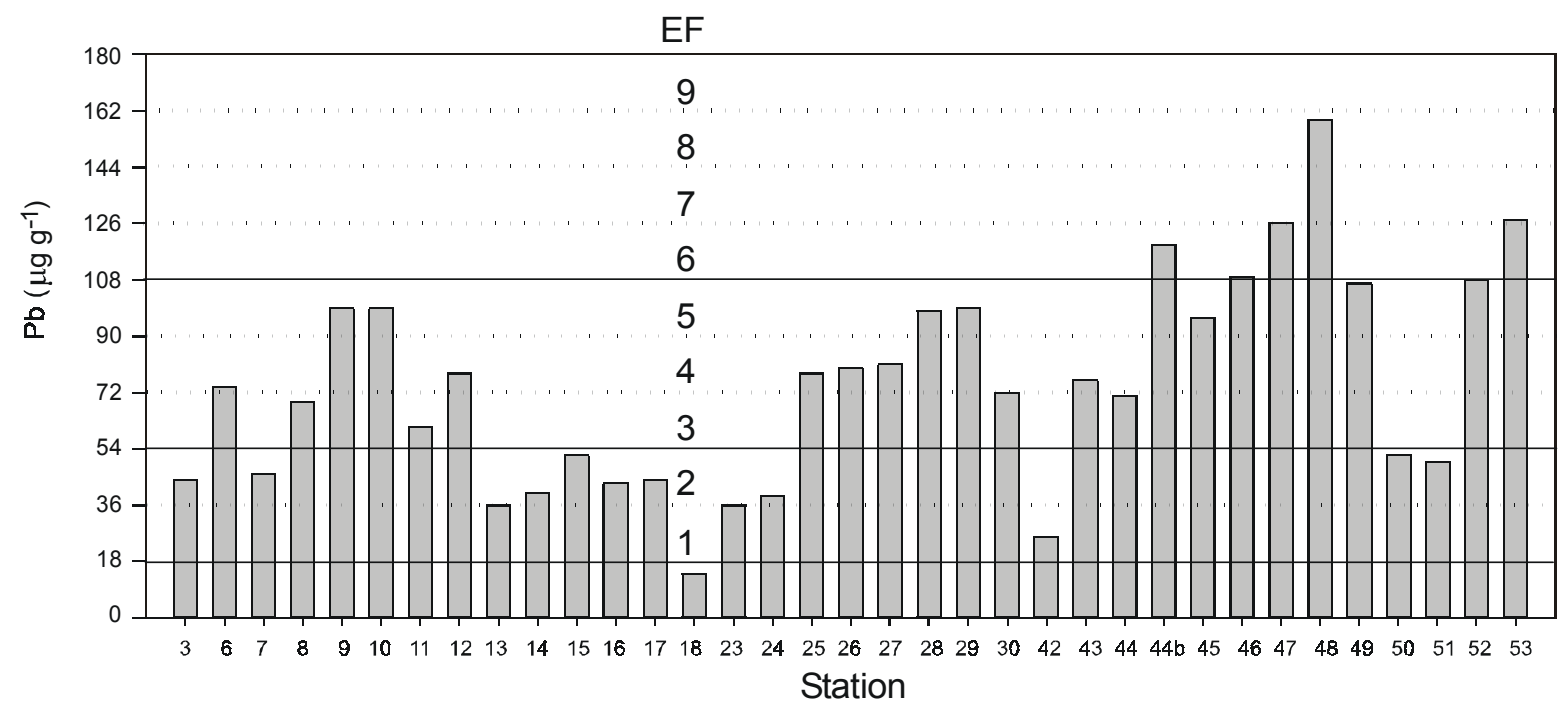

Figure 5. Lead contamination levels in the surface sediment of the Ría of Ferrol expressed as enrichment factors (EF). Figura 5. Estado de contaminación por plomo en la Ría de Ferrol, de acuerdo con los valores del factor de enriquecimiento (EF) en las muestras extraídas del sedimento superficial. 
Generally speaking, the samples obtained in the Ria of Ferrol show EFs ranging from 2 to 6 (fig. 5), that is, a moderate to considerable contamination for lead in this ria. Out of this general findings are: (a) samples with concentrations similar to the natural background value, stations 42 and 3 at the mouth of the ria; stations 7, 22 (with the lowest $\mathrm{EF}=0.8$ ), 23 and 24 in the southern margin; stations 13, 14, 15, 16, 50 and 51 located in the inner part under strong tidal currents due to the funneling effect caused by land filling for the construction of two bridges; (b) samples with high contamination, which are located in the vicinity of the harbor area (stations 44b, 46, 47, 48 -with the highest $\mathrm{EF}=9.3$ - and 49), and also in the northern margin of the innermost part of the ria (stations 52 and 53) in the vicinities of the iron and steel production facilities.

The existence of these different areas in the Ria of Ferrol with different contamination levels agrees with the previously reported results based on biomonitoring (Carballeira et al., 1997) using Scrobicularia plana and Enteromorpha sp.

\section{Acknowledgements}

Thanks to Jorge Alonso, captain of the R/V Mytilus and his crew for the help provided during the sampling campaign; to the Instituto de Geologia (ULC) for the samples of deep sediment; and to Montserrat Martínez and Juan R. González for their technical assistance. A. Cobelo-García thanks the Spanish Ministry of Science and Technology for its financial support (FPI grant). This paper is a contribution to the project "Biogeochemical processes in the Ria of Ferrol: origin of its fertilization by nutrients and spatial and historical variation of metals in sediment" (ref. 1FD97-0479-C03-02) financed by FEDER-CYCIT.

\section{References}

Belzunce, M.J., Helios-Rybicka, E. and Prego, R. (1997a). Distribution of heavy metals in the River Ulla and its estuary (North-West Spain). J. Oceanol. Stud., 2-3: 139-152.

Belzunce, M.J., Bacon, J.R., Prego, R. and Wilson, M J. (1997). Chemical forms of heavy metals in surface sediments of the San Simón Inlet, ría de Vigo, Galicia. J. Environ. Sci. Health. Part A. 32(5): 1271-1292.

Belzunce, M.J., Prego, R. and Wilson, M.J. (2000). Distribución del $\mathrm{Pb}$ en la ría de Vigo: estudio total y de las formas químicas. In: A. Da Costa Duarte, C. Vale and R. Prego (eds.), Estudos de Biogeoquímica na Zona Costeira Ibérica. Servicio de Publicaciones de la Universidad de Aveiro, Aveiro (Portugal).

Bermejo-Barrera, P., Barciela-Alonso, C., Aboal-Somoza, M. and Bermejo-Barrera, A. (1994). Slurry sampling for determination of lead in marine sediments by Electrothermal Atomic Absorption Spectrometry using palladium-magnesium nitrate as chemical modifier. J. Anal. At. Spectrom., 9: 469-475.

Besada, V., Schultze, F. y Viñas, L. (1997). Distribución de metales pesados en sedimentos superficiales de la ría de Vigo. In: R. Prego and J.M. Fernández (eds.), Procesos Biogeoquímicos en Sistemas Costeros Hispano-Lusos. Servicio de Cultura de la Diputación de Pontevedra, Pontevedra (Spain), pp. 79-85. obtenido por esta vía, BVs de $78 \mu \mathrm{g} \mathrm{g}^{-1}$ de $\mathrm{Pb}$ para dominios litológicos de granito y de $50 \mu \mathrm{g} \mathrm{g}^{-1} \mathrm{de} \mathrm{Pb}$ para los de esquisto $\mathrm{y}$ gneis.

A fin de calcular los EF en la ría de Ferrol se ha preferido determinar los BV a partir de niveles naturales preindustriales obtenidos mediante perfiles sedimentarios perfectamente datados. Para ello es normal utilizar como nivel de referencia en el testigo las capas más antiguas (Establier et al., 1985) y, por lo tanto, se tomaron muestras entre 130 y $170 \mathrm{~cm}$ de profundidad en un testigo extraido con un "vibro-corer" en un punto central de la ría (junto a la estación 9, fig. 1). Se obtuvo un nivel natural de fondo, $\mathrm{BV}$, de $18.2 \mu \mathrm{g} \mathrm{g}^{-1} \mathrm{de} \mathrm{Pb}$, que corresponde a 3745 \pm 70 años de antigüedad por datación mediante ${ }^{14} \mathrm{C}$ a $161 \mathrm{~cm}$ de profundidad (Santos y Vidal-Romaní, 2000).

El nuevo BV determinado es menor que el anteriormente propuesto para el sedimento de las rías, empero, es más cercano al valor de $32 \mu \mathrm{g} \mathrm{g}^{-1}$ de $\mathrm{Pb}$ para granitos y $16 \mu \mathrm{g} \mathrm{g}^{-1} \mathrm{de} \mathrm{Pb}$ para esquistos y gneises propuesto por Wedepohl (1991) para esos dominios a nivel mundial.

Con el nivel de fondo propuesto para el plomo en el sedimento de la Ría de Ferrol se obtienen los factores de enriquecimiento recogidos en la figura 5. Ahora, la consideración de los grados de contaminación se hace de acuerdo con la clasificación propuesta por Hakanson (1980) en lagos suizos: ausente $<1>$ moderada $<3>$ considerable $<6>$ muy alta.

En general, las muestras obtenidas en Ferrol presentan un EF comprendido entre 2 y 6 (fig. 5), esto es, una contaminación de moderada a considerable para esta ría. Salen de esta consideración: (a) por defecto, con niveles casi naturales, las muestras correspondientes a las estaciones 42 y 3 en la boca; 7 , 22 (la de más bajo EF con 0.8), 23 y 24 en la margen sur; y las estaciones $13,14,15,16,50$ y 51 , situadas en una zona sujeta a fuertes corrientes debido a un estrechamiento en la parte interna de la ría a causo de rellenos hechos para la ubicación de dos puentes; (b) por el contrario, son considerables como de alta contaminación las estaciones próximas a la zona portuaria, estaciones 44b, 46, 47, 48 (la de mayor EF con 9.3) y 49; y también la margen norte del fondo de la ría, estaciones 52 y 53 , próximas a una industria siderúrgica.

Esta zonificación de la contaminación por plomo obtenida para la Ría de Ferrol a través del sedimento confirma resultados puntuales anteriores basados en especies biomonitoras (Carballeira et al., 1997) como Scrobicularia plana y Enteromorpha sp.

\section{Agradecimientos}

Agradecemos la colaboración prestada en los trabajos de muestreo a Jorge Alonso, capitán del B/O Mytilus, así como a su amable tripulación; al Instituto de Geología (ULC) por las muestras de sedimento profundo; y a Monserrat Martínez y Juan R. González por la ayuda técnica prestada. A. CobeloGarcía agrecede al Ministerio de Ciencia y Tecnología español por el apoyo financiero (Beca FPI). Este artículo es una contribución a los proyectos "Procesos biogeoquímicos en la 
Prego et al:: Lead levels in the sediments of the Ria of Ferrol

Branica, M. and Konrad, Z. (eds.) (1980). Lead in the Marine Environment. Pergamon Press, Oxford, 353 pp.

Carballeira, A., Carral, E. Puente, X.M. y Villares, R. (1997). Estudio de Conservación de la Costa de Galicia. Xunta de Galicia, Santiago de Compostela, 107 pp.

Carral, E., Villares, R., Puente, X. and Carballeira, A. (1995). Influence of watershed lithology on heavy metal levels in estuarine sediments and organisms in Galicia (North-West Spain). Mar. Poll. Bull., 30: 604-608.

Chow, T.J. (1978). Lead in natural waters. In: J.O. Nriagu (ed.), The Biogeochemistry of Lead in the Environment. Amsterdam, pp. $185-218$

Establier, R., Gómez-Parra, A. and Blasco, J. (1985). Superficial accumulation of heavy metals in near shore marine sediments: an objetive index of environmental pollution. Bull. Environ. Contam. Toxicol., (35): 348-353.

Ewers, U. and Schkipköter, H. W. (1991). Lead. In: Metals and their Compounds in the Environment. VCH, Weinheim, pp. 971-1014.

Fowler, S.W. (1977). Trace elements in zooplancton particulate products. Nature Lond., 269: 51-53.

Förstner, U. (1980). Inorganic Pollutants, Particulary Heavy Metals in Estuaries. In: E. Olausson and I. Cato (eds.). John Wiley, Chichester, pp. 306-348.

GESAMP (1985). Cadmium, lead and tin in the marine environment. UNEP Regional Seas Reports and Studies, $\mathrm{n}^{\circ}$ 56, $85 \mathrm{pp}$.

Gordeev, V.V. (1986). Lead and cadmium in river suspended matter. Proceeding of a UNESCO/IOC/CNA Workshop, Lisbone.

Guerrero-Pérez, J., Rodríguez Puente, C. y Jornet Sancho, A. (1988). Estudio de metales pesados en aguas y sedimentos superficiales en las costas Cantábrica y Gallega. Inf. Téc. Inst. Esp. Oceanogr., $\mathrm{n}^{\mathrm{o}} 64,16 \mathrm{pp}$.

Hakanson, L. (1980). An ecological risk index for aquatic pollution control. A sedimentological approach. Water Res., 14: 975-1001.

Hansen, H.P. and Grasshoff, K. (1983). Automated chemical analysis. In: Methods of Seawater Analysis. Verlag Chemie, Weinheim, pp. 368-376.

Herbello, P y Prego, R. (1998). Situación actual del estudio de los metales pesados, Plomo, Cobre y Cromo en las rias de Galicia (NW de España). Monogr. Química Oceanográfica, 2(98): 1-20.

IDASA. (1987). Plan de saneamiento para cinco sistemas de Rias en Galicia (Ferrol, A Coruña, Arousa-Umia, Pontevedra y Vigo): COTOP, Xunta de Galicia, Santiago de Compostela, 95 pp.

IGE (1995). Galicia en cifras. Anuario 1994. Consellería de Economía e Facenda, Xunta de Galicia, Santiago de Compostela, 262 pp.

Lueiro, X y Prego, R. (1999). La ría de Ferrol: Revisión de su conocimiento. Monogr. Química Oceanográfica, 1(99): 1-30.

López-Jamar, E., Bode, A., Parra, S. y Vázquez Dorrio, A. (1996). Consecuencias del vertido de crudo del Agean Sea sobre la macrofauna bentónica submareal. In: J. Ros (ed.), Seguimiento de la Contaminación Producida por el Accidente del Buque Agean Sea. Ministerio del Medio Ambiente, Madrid, pp. 69-106.

Martin, J.H. and Knauer, G.A. (1973). The elemental composition of plancton. Geochim. Cosmochim. Acta, 37: 1639-1653.

Metallstatistik (1988). Frankfurt Ann Main (75 ed.).

Mortlock, R.A. and Froelich, P.N. (1989). A simple method for the rapid determination of biogenic opal in pelagic marine sediments. Deep-Sea Res., 36: 1415-1426.

Murozumi, M., Chow, T.J. and Patterson, C.C. (1969). Chemical concentration of pollutant lead aerosols, terrestrial dust and sea
Ría de Ferrol: origen de su fertilización por sales nutrientes y variación espacial e histórica de metales en el sedimento" (ref. 1FD97-0479-C03-02) financiado con fondos FEDER-CYCIT.

Traducido al español por los autores.

salts in Groenland and Artic snow strata. Geochim. Cosmochim. Acta, 33: 1247-1294.

Nriagu, J.O. (1978). Biogeochemistry of Lead in the Environment. Elsevier, Amsterdan.

Prego, R. (1995). La interacción acuicultura-agua marina. Aspectos generales en las rías gallegas. In: J. Penas (ed.), Acuicultura e cultivos mariños en Galicia, Edicios do Castro, Sada, pp. 25-38.

Prego, R. (1993). Eutrofización de las aguas costeras gallegas. In: J. Penas (ed.), A Contaminación Mariña do Litoral Galego, Ediciós do Castro, Sada, pp. 25-48.

Prego, R. and Fraga, F. (1992). A simple model to calculate the residual flows in a Spanish ria. Hydrographic consequences in the ria of Vigo. Estuar. Coast. Shelf Sci., 34: 603-615.

Prego, R. and Cobelo-García, A. (2003). 20th Centrury overview of heavy metals in the Galician rias (NW Iberian Peninsula). Environ. Poll., 121: 425-452.

Reinfleder, J.R. and Fisher, N.S. (1991). The assimilation of elements ingested by Marine Copepods. Science, 251: 794-796.

Rio, F.X. y Rodríguez, F. (1992). Os Rios Galegos: Morfoloxía e Réxime. Consello da Cultura Galega, Santiago de Compostela, $319 \mathrm{pp}$.

Robinson, I.M. (1978). Lead as a factor in the world economy. In: The Biogeochemistry of Lead in the Environment. Elsevier, Amsterdam, pp. 99-118.

Santos, L. y Vidal-Romaní, J.R. (2000). Paleoambiente holoceno (3700 años BP-Presente) en la ria de Ferrol, A Coruña. Libro de Resúmenes del XIII Simposio de la Asociación de Polinólogos en Lengua Española (A.P.L.E.). Cartagena, 183 pp.

Soto, B. y Diaz-Fierros, F. (1996). As augas de Galicia balance hídrico. In: F. Díaz-Fierros (ed.), As Augas de Galicia, Consello de Cultura Galega, Santiago de Compostela, pp. 107-146.

Stanford, H.M., O Connor, J.S. and Swanson, R.L. (1981). The effects of ocean dumping on the New York Bight ecosystem. In: B.H. Ketchum, D.R. Kester and P. Kilho (eds.), Ocean Dumping of Wastes. Plenum Press, New York, pp. 53-86.

Taylor, D. (1981). A summary of the data on the toxicity of various materials to aquatic life: Lead. ICI Report No. BL/A/2126, Brixham, 34 pp.

Torre-Enciso, E. (1958). Homenaxe a Otero Pedrayo. Galaxia Santiago de Compostela, pp. 237-250.

US EPA. (1980). Ambient water quality criteria for lead. US EPA No. 440/5-80-057. US Environmental Protection Agency, Criteria and Standar Division, Washington, $161 \mathrm{pp}$.

Varela, M., Bode, A., Alvarez, M.T., Prego, R., Canle, M., Casas, B., Lorenzo, J., Mariño, D., González, I., Carballo, R. y Vilas, M. (1996). Sistema Pelagico. In: J. Ros (ed.), Seguimiento de la contaminación producida por el accidente del buque Aegean Sea, Ministerio de Medio Ambiente, Madrid, pp. 19-68.

Wedephol, K.H. (1991). Metals and their Compounds in the Environment. VCH, Weinhein, pp. 3-17. 